\title{
FILSAFAT MANUSIA ALI SYARI'ATI: KESADARAN DAN KEBEBASAN MANUSIA DI ERA REVOLUSI TEKNOLOGI 4.0
}

\author{
Fitri Cahyanto \\ Aqidah dan Filsafat Islam, Institut Agama Islam Negeri Surakarta \\ Fitricahyanto0@gmail.com
}

\begin{abstract}
Abstrak
Filsafat manusia mulai dikaji secara rasional sejak zaman Yunani kuno. Hingga saat ini filsafat manusia masih menjadi bidang kajian yang terus dikembangkan sesuai dengan semangat zamannya. Salah satu tokoh Muslim yang berhasil memproduksi filsafat manusia ialah Ali Syari'ati. Dengan menggunakan pendekatan rasio-empiris serta tidak melepaskan dogma-dogma Islam. Studi ini mencoba mengungkap dan menghadirkan kembali pemikiran filsafat manusia Ali Syari'ati dengan menggunakan pendekatan kesinambungan historis, analisis kritis, dan deskripsi interpretasi. Zaman kemajuan teknologi yang segalanya serba cepat, terutama dalam penggabungan antara infotek dan biotek yang dikemas dalam satu data besar serta kemunculan artificial intelegent yang mampu bekerja seperti manusia bahkan lebih baik. Pada hakikatnya teknologi merupakan suatu alat yang ditemukan manusia untuk menjadi perpanjangan tangan, bukan menjadi pemegang otoritas dari kehendak manusia. Teknologi kini mengambil tugas vital manusia yakni kesadaran dan kebebasan manusia, bagian inti sebagai indikator bahwa manusia itu adalah manusia yang seutuhnya. Melalui filsafat manusia Ali Syari'ati mencoba mengembalikan fitrah manusia agar tetap sadar dan bebas terhadap dirinya sendiri dalam mengambil suatu keputusan.
\end{abstract}

Kata Kunci: Basyar, Insan, Artificial Intelegent, Algoritma

\begin{abstract}
Human philosophy began to be studied rationally since ancient Greece. Now human philosophy is still a field of study that continues to be developed in accordance with the spirit of his era. Ali Syari'ati was a Muslim figure who succeeded in producing human philosophy, by using an empirical ratio approach and not letting go of Islamic dogma. This study attempts to uncover and represent Syari'ati's philosophical human thought using an historical continuity approach, critical analysis, and description of interpretation. The era of technological advances, everything is fast-paced, especially in the combination of infotek and biotech that is packaged in one big data and the emergence of artificial intelligence that is able to work like humans is even better. In essence, technology is a tool found by humans to become an extension, not to become an authority holder of human will. Technology now takes on the vital task of man, namely human awareness and freedom, a core part of the indicator that humans are fully human. Through human philosophy Ali Syari'ati tried to restore human nature to stay aware and free of himself in making a decision.
\end{abstract}

\section{Keywords: Basyar, Insan, Artificial Intelegent, Algoritma}




\section{Pendahuluan}

Manusia selalu berkembang dari setiap mileniumnya. Perkembangan dari revolusi kognitif (kurang lebih 150.000 tahun silam) menuju revolusi pertanian (kurang lebih 10.000 tahun silam) kemudian revolusi sains (abad 15-17 M), hal itu semua yang menjadi cikal bakal kemajuan pada saat ini yakni revolusi teknologi. Sebagian dari genus Homo pada era revolusi kognitif sampai revolusi pertanian meyakini bahwa manusia ikut ambil bagian dari rencana besar yang dirancang oleh Tuhan atau hukum alam pusat dan manusia tidak dapat mengubahnya. ${ }^{1}$ Homo menganggap bahwa dunia ini seperti panggung dan makhluk di muka bumi ini adalah aktornya yang dikendalikan oleh pemain dibalik layar, dan pemain itu adalah Tuhan. Seperti halnya para homo sapiens yang berhasil melintasi ambang kritis dan akhirnya mampu mendirikan kota-kota yang berisi puluhan ribu penduduk dan imperium-imperium yang memerintah ratusan juta jiwa. Rahasianya terdapat pada kemunculan fiksi yang diyakini banyak orang. Banyak orang yang belum mengenal satu sama lain mampu bekerja sama atas nama dewa/Tuhan hasil dari fiksi yang diciptakan manusia. Mereka meyakini bahwa hal itu merupakan tugas yang diberikan oleh dewa. ${ }^{2}$ Kisah serupa terdapat pada zaman gereja abad pertengahan dimana seorang pemuka agama dapat memerintahkan ataupun memegang otoritas pengikutnya atas nama Tuhan.

Imagined orders (tatanan khayal) yang diyakini ini berlangsung selama bertahun-tahun kini sedikit demi sedikit mulai tergeser pada era modern. Era modern merupakan sebuah era sains yang mendasari tingkat suatu kebenaran pada pengumpulan-pengumpulan data empiris, sehingga bisa disebut juga dengan revolusi sains. Era ini terjadi pada abad ke-15 dan mengalami puncaknya pada abad ke-17. Masa transformasi ini menjadi titik balik dari kemajuan teknologi yang kita rasakan pada abad ke-21. Keyakinan yang mengakar selama puluhan ribu tahun silam itu mencoba digeser dengan suatu pembuktian nyata. Pada saat masa transisi, terjadi pemberontakan terhadap otoritas gereja, dengan bentuk penolakan terhadap dogma-dogma. Manusia saat itu kemudian menggunakan kemampuan mereka untuk melakukan observasi sistematis. Kini manusia mulai mempercayai hasil yang keluar dari suatu laboratorium dari pada mempercayai dongeng-dongeng para leluhur. Pembebasan dari otoritas gereja mendorong tumbuhnya individualisme, disiplin intelektual, humanisme, moral dan politik. ${ }^{3}$

Manusia modern memiliki kultur menolak rencana besar kosmis. Mereka meyakini bahwa manusia lebih besar daripada aktor panggung kehidupan. Bahkan kehidupan tidak memiliki naskah

${ }^{1}$ Yuval Noah Harrari, Homo Deus a Brief History of Tomorrow, Terj Yanto Mustofa, (Tanggerang Selatan: PT Pustaka Alfabet, 2018), 229.

${ }^{2}$ Yuval Noah Harrari, Sapiens, Terj Damaring Tyas Wulandari Palar, (Jakarta: PT Gramedia, 2018), 32.

${ }^{3}$ Bertrand Russell, History of Western Philosophy and its Connection with Political and sosial Circumstances from the Earliest Times to the Present Day, Terj Sigit Jarmiko dkk, (Yogyakarta: Pustaka Pelajar, 2016), 647. 
drama dan tidak punya pengarang. Manusia modern mempercayai bahwa ia merupakan pusat dari kehidupan. Oleh karena itu manusia mampu melakukan apapun yang dia kehendaki. Kesadaran manusia akan kemampuanya membuat mereka melakukan investasi untuk riset, melakukan suatu terobosan saintifik untuk memacu kemajuan teknologi. Kultur modern adalah yang terkuat dalam sejarah karena ia tiada berhenti melakukan riset, menemukan, menciptakan dan tumbuh. ${ }^{4}$

Pada abad 21 terlalu rendah untuk membandingkan manusia dengan mesin uap. Revolusi saintifik abad 17 yang terjadi di eropa sebagai bentuk lompatan untuk sains pada abad seterusnya. Sebuah usaha yang dilakukan Newton menemukan gaya gravitasi untuk membangun sebuah kosmologi baru. Style filsafat alam dengan membawa suatu visi cara berfikir yang baru, bahwa segalanya dapat dihitung dan diukur. ${ }^{5}$ Style filsafat ini memberi pengaruh dalam ilmu biologi sehingga mengalami kemajuan. Ilmu biologi menyatakan bahwa setiap organisme adalah algoritma yang bisa direpresentasikan dalam matematika. Seperti rasa takut atau kecerdasan manusia sehingga berlari menjauh saat bertemu dengan singa. Peristiwa ini dimaknai dengan pengalaman subjektif, akan tetapi para ilmuan menyediakan penjelasan secara terperinci. Ketika seseorang melihat singa, sinyal-sinyal elektrik bergerak dari mata ke otak, kemudian menstimulasi neuron-neuron tertentu yang bereaksi dengan menembakkan sinyal-sinyal. Jika cukup neuron-neuron yang tepat menembakkan sinyal pada kecepatan yang cukup cepat, maka perintah dikirim ke kelenjar adrenal untuk membanjiri tubuh dengan adrenalin, jantung diperintahkan berpacu lebih kencang, sementara neuron-neuron dalam pusat pengendalian gerak (motorik) mengirim sinyal ke bawah, ke otot-otot kaki, yang mulai meregang dan berkontraksi, dan orang itu lari dari singa. Penggabungan antara biologi dan teknologi memunculkan teknologi baru yang dikenal dengan Artificial Intelegent (kecerdasan buatan). ${ }^{6}$

Revolusi teknologi kali ini menyadari bahwa AI (Artificial Intelegent) bukan hanya komputer yang semakin cepat dan semakin pintar. Kemajuanya dalam sains hayati (life Sciences) dan sains sosial (Sosial Sciences) juga turut serta memicu AI untuk menjadi semakin baik. Semakin baik dalam memahami mekanisme biokimia yang mendukung hasrat, emosi dan pilihan manusia, semakin komputer menjadi lebih baik dalam menganalis dan memprediksi keputusan manusia. ${ }^{7}$ AI kini mampu menentukan yang terbaik bagi manusia, dengan kalkulasi-kalkulasi logis yang super cepat AI mampu memberikan rekomendasi untuk manusia terhadap segala hal. Bahkan manusia kini serasa tidak berguna dihadapan AI dengan algoritmanya karena penemuan baru dalam teknologi kini mampu menganalisa manusia lebih baik daripada manusia itu sendiri. Otoritas secara perlahan

${ }^{4}$ Yuval Noah Harrari, Homo Deus a Brief History of Tomorrow, 231.

${ }^{5}$ Husain Heriyanto, Revolusi Saintifike di Iran, (Jakarta: Universitas Indonesia Press, 2013), 187.

${ }^{6}$ Yuval Noah Harrari, Homo Deus a Brief History of Tomorrow, 127-128. 2018), 22.

7 Yuval Noah Harrari, 21 Lessons for the 21 ${ }^{15 t}$ Century, Terj Haz Algebra, (Manado: CV. Global Indo Kreatif, 
mulai bergeser dari manusia ke algoritma. Manusia kini lebih mempercayai Instagram, Netflix, Google, Facebook, dan bentuk-bentuk AI lainya. Tanpa adanya data-data tersebut manusia akan merasa kehilangan sebagian dari dirinya. Jika kita berfikir, siapa yang menulis data dalam Instagram, Facebook dan yang lainya? Maka jawabanya adalah kita semua, manusialah yang telah mengisinya. Dalam sebuah big data, algoritma individu manusia hanya menjadi komponen mungil dalam sebuah sistem yang tak seorang pun benar-benar memahaminya. Setiap hari manusia menyerap, menulis dan membagikan data yang tak terhitung jumlahnya melalui smartphone, komputer dll. Manusia tidak tau di mana kedudukanya dalam skema hal-hal yang lebih besar karena berada dalam tumpukan data yang tercipta dari milliaran manusia dan saling terhubung. Manusia terlalu sibuk melihat jumlah like dan menanggapi komentar dari postingan indahnya senja disore hari, tanoa menyadari sebenarnya yang telah dia lakukan dihari itu. Teknologi kini mendefinisikan manusia adalah data yang telah ia proses. ${ }^{8}$

Humanisme pada abad 21 mulai terkikis dihadapan revolusi teknologi. Jiwa dari humanisme terletak pada individu manusia, kebebasan memilih dan subjektifitas manusia sebagai pusat kehidupan di dunia, namun hal itu terbentur dengan teknologi. Kehendak manusia kini disandarkan kepada AI, belok ke kiri atau ke kanan diserahkan kepada google, mesti hasilnya bertentangan dengan hati Nurani manusia kini lebih mempercayai google. Manusia hilang dalam arus deras data yang saling bertumpukan. Manusia yang menurut pandangan humanisme Ali Syari'ati adalah sebagai pusat dari kehidupan sekaligus menjadi wakil Tuhan yang ada di bumi karena memili sifat dan unsur terpenting dari Tuhan yakni ruhnya. ${ }^{9}$ Akan tetapi manusia kini hanya menjadi sebuah komponen mungil dari sistem. Bagaimana mau mewujudkan tujuan untuk memaksimalkan perkembangan manusia jika esensi dari manusia yakni kebebasan dan kesadaranya terbelenggu.

Kemajuan teknologi yang mulai mengambil alih ranah vital manusia yakni kesadaran dan kebebasan, sebab hal itu menjadi penting untuk membahas kembali manusia pada abad 21 ini. Ali Syari'ati merupakan salah satu tokoh dari Iran yang memiliki perspektif terkait manusia dengan menggunakan metode-metode dari barat akan tetapi masih kental dengan dogma-dogma islam. ${ }^{10}$ Menurut Ali Syari'ati, kisah tentang penciptaan Adam dalam Al-Qur'an adalah ungkapan humanisme yang mendalam dan maju. Adam mewakili seluruh spesies manusia, esensi umat manusia, manusia dalam pengertian filosofis bukan dalam pengertian biologis. Ketika Al-Qur'an berbicara tentang manusia dengan pengertian biologis seperti sperma, tetesan darah, janin itu

\footnotetext{
8 Yuval Noah Harrari, Homo Deus a Brief History of Tomorrow, 443.

${ }^{9}$ Ali Syari'ati, Manusia dan Islam Sebuah Kajian Sosiologi, Terj Ashar R W, (Yogyakarta: Cakrawangsa, 2017), 94.

10 Sabara, "Pemikiran Teologi Pembebasan Ali Syari'ati", dalam Journal Al-Fikr Vol. 20, No. 2, (September 2016), 215.
} 
berarti Al-Qur'an menggunakan bahasa ilmu-ilmu alam. ${ }^{11}$ Namun ketika sampai pada penciptaan Adam, bahasa Al-Qur'an adalah metaforis dan filosofis serta penuh makna dan simbol. ${ }^{12}$

Penciptaan manusia menurut Ali Syari'ati terdiri dari dua formula yaitu, roh Tuhan dan tanah liat ${ }^{13}$ atau lempung berbau ${ }^{14}$. Tanah liat bermakna kerendahan, stagnasi dan kepasifan. Sedangkan roh Tuhan menunjukan makna gerakan tidak ada akhir menuju kesempurnaan dan kemuliaan tak terhingga. Manusia sebagai wakil Tuhan diciptakan dari bahan yang terendah (tanah liat), akan tetapi Allah menghembuskan ke dalamnya roh-Nya. Pada akhirnya kedua unsur ini saling tarik menarik sehingga manusia harus menentukan pilihanya sendiri. Oleh karena itu manusia merupakan makhluk yang memiliki kehendak bebas untuk menentukan nasibnya sendiri. Apakah ia akan terperosok ke dalam endapan tanah liat ataukah ia akan meningkat ke arah kutub yang mulia. ${ }^{15}$

Setelah menyelesaikan kejadian manusia, Allah menjadi guru pertama manusia dan pelajaran pertamanya adalah pengenalan nama-nama. Hal itu mengganggu para malaikat yang kemudian memprotes, "Kami diciptakan dari api tanpa asap, sedangkan manusia diciptakan dari tanah liat, kenapa engkau melebihkanya dari kami?” Allah menjawab, “Aku mengetahui apa yang tidak kalian ketahui, bersujudlah pada makhluk-Ku yang mempunyai dua dimensi ini". ${ }^{16}$ kejadian ini merupakan arti sebenarnya dari humanisme. Islam mengangkat derajat manusia di atas para malaikat. Keunggulan ini bukan secara rasial akan tetapi dari intelektual manusia yang dibuktikan lebih tinggi dari malaikat. ${ }^{17}$

Maka dari itu, manusia harus melakukan evolusi, dari kerendahan menuju kemuliaan. Karena manusia merupakan manifestasi dari sifat-sifat Tuhan, dan mampu berbuat mirip seperti tuhan dan tidak mampu menjadi Tuhan. Manusia dapat bertindak melawan ketentuan-ketentuan makhluk fisiologis. Jadi kedekatan manusia dengan Tuhan berasal dari keutamaan yang sama yakni kemauan bebas. ${ }^{18}$ Kemudian manusia harus mampu evolusi dari basyar ke insan. Dalam proses menuju tahap yang lebih sempurna, menurut Ali Syari'ati ada empat penjara yang merintangi yaitu sifat dasar atau belenggu alam, sejarah, masyarakat dan ego manusia sendiri. Manusia harus mampu membebaskan dari cengkeraman deterministik itu untuk mengubah kedudukanya. ${ }^{19}$

11 Ali Syari'ati, Sosiologi Islam Pandangan Dunia Islam dalam Kajian Sosiologi untuk Gerakan Sosial Baru, Terj Arif Mulyadi, (Yogyakarta: Rausyan Fikr Institute, 2011), 127.

12 Ali Syari'ati, Manusia dan Islam Sebuab Kajian Sosiologi, 89.

13 Ali Syari'ati, Sosiologi Islam Pandangan Dunia Islam dalam Kajian Sosiologi untuk Gerakan Sosial Baru, 128.

14 Ali Syari’ati, Tugas Cendekiawan Muslim, Terj M. Amien Rais, Jakarta: Rajawali, 1987), 7.

15 Ali Syari'ati, Manusia dan Islam Sebuah Kajian Sosiologi, 93-95.

16 Ali Syari'ati, Manusia dan Islam Sebuah Kajian Sosiologi, 95.

17 Ali Syari'ati, Tugas Cendekiawan Muslim, 9.

18 Ali Syari'ati, Tugas Cendekiawan Muslim, 12.

${ }^{19}$ M Deden Ridwan (ed), Melawan Hegemoni Barat Ali Syariati dalam Sorotan Cendekiawan Indonesia, Jakarta: PT Lentera Basritama, 1999), 90. 
Kebebasan dan kesadaran manusia sejatinya telah menjadi fitrah. Apabila hal itu terus dipegang teguh maka manusia akan senantiasa berkembang, berproses menuju manusia yang unggul. 4 penjara yang menjadi penghalang merupakan konsep yang ditelurkan pada abad 20 . Secara subtansi menurut Michel Foucault penjara merupakan sebuah institusi yang memiliki tugas untuk mengawasi dan mengurung manusia. ${ }^{20}$ Kini teknologi yang seharusnya menjadi alat bantu dari manusia justru menjadi penjara bagi manusia. Menyumbat aliran kesadaran dengan tumpukan data. Membelenggu manusia dengan derasnya data algoritma. Oleh karena itu perlu mengkaji filsafat manusia Ali Syari'ati agar manusia tetap sadar dan bebas serta mampu menjadi manusia yang unggul.

\section{Pengertian Manusia}

Manusia senantiasa berkembang dan berubah sesuai dengan keinginannya. Hanya manusia yang mampu membuat peristiwa, mengejar impian atau melakukan nilai, karena manusia diberikan kemerdekaan atas dirinya sendiri. Kenyataan ini sekaligus menunjukkan bahwa sejarah tidak boleh dipahami atau ditafsirkan sebagai perubahan semata-mata, melainkan harus dilihat dari sesuatu yang substansial. ${ }^{21}$ Masalah manusia adalah yang paling penting dari segala masalah. Peradaban dewasa ini telah mendasarkan fondasi agamanya pada humanisme. Akar-akar yang berasal dari Athena sebagai reaksi keras terhadap filsafat skolastik dan agama pada abad pertengahan. Menurut Ali Syari'ati proses penciptaan Adam memiliki sifat humanisme yang mendalam. Penciptaan Adam yang merupakan simbol manusia dalam kitab-kitab suci Islam, di mana Islam merupakan kulminasi dan perfeksi, diceritakan dalam bahasa simbolik.

Pada awalnya Tuhan memberitahu para malaikat bahwa Dia ingin menciptakan wakil-Nya di atas bumi. Betapa mulia nilai manusia sebagai pengganti-Nya di atas bumi, Tuhan menganugerahkan status spiritual tertinggi bagi manusia dan dengan demikian mempercayakan padanya misi suci di alam raya ini. ${ }^{22}$ Manusia mengemban misi suci untuk mewakili Tuhan dan mencerminkan kualitas-kualitas-Nya di atas bumi. Ada sifat pencipta yaitu, Dialah yang menciptakan segala sesuatu di atas bumi. Ada sifat berkehendak yaitu, dunia bergerak dan dibimbing melalui keinginan-Nya. Sifat yang lain ialah sifat yang mengatur eksistensi dan yang memiliki pandangan dan kesadaran absolut ke seluruh alam. ${ }^{23}$

Sifat kesucian khas yang dikaruniakan kepada manusia membuat malaikat bertanya "apakah Tuhan akan menciptakan makhluk yang akan menumpahkan darah, berbuat kejahatan, menebarkan kebencian dan balas dendam?" kemudian Tuhan menjawab "Aku mengetahui apa

\footnotetext{
20 Michel Foucault, Power or Knowledge, Terj Yudi Santosa, (Yogyakarta: Bentang Budaya, 2002), 51-52.

${ }^{21}$ Daliman, Manusia dan Sejarah, (Yogyakarta: Penerbit Ombak, 2012), 9-10.

22 Ali Syari'ati, Tugas Cendekiawan Muslim, 4-6.

23 Ali Syari'ati, Agama Versus "Agama", Terj Afif Muhammad, (Bandung: Pustaka Hidayah, 1994), 29.
} 
yang tidak kamu ketahui." Mulailah manusia diciptakan sebagai wakil dan khalifah-Nya, dari tanah atau lumpur (bentuk yang paling rendah) dan Roh-Nya (betuk yang paling mulia) ${ }^{24}$ Lumpur dalam bahasa manusia merupakan simbol kerendahan, kenistaan dan kekotoran. Sedang Tuhan dalam bahasa manusia adalah simbol kesempurnaan dan kesucian. Sebagai gabungan dari lumpur dan Roh suci, manusia telah diciptakan menjadi makhluk dua dimensional, dengan dua arah dan kecenderungan. Pertama, menuju ke arah stagnasi, ke dasar hakekatnya yang rendah di mana seluruh dorongan dan gerak kehidupannya akan membeku, terbenam pada hakikatnya yang hina. Kedua, dimensi manusia yang lain yaitu dimensi spiritualnya, cenderung naik ke puncak spiritual tertinggi (zat yang Maha Suci). ${ }^{25}$

Manusia adalah makhluk dua unsur yang kontradiktif, dengan dua kutub saling berseberangan yang dimilikinya. Pada hakekatnya dua kutub itu memungkinkan manusia untuk memiliki kebebasan memilih antara dua pilihan yaitu, kutub kehinaan dan kutub kesucian, yang keduanya ada pada dirinya. Perjuangan dan peperangan terus-menerus yang dilakukan oleh kedua kutub itu dalam diri manusia akhirnya akan memaksa manusia untuk memilih salah satu kutub tersebut yang akan menentukan nasibnya.

Setelah terciptanya manusia, Allah kemudian mengajarkan nama-nama kepadanya. Setiap orang atau penafsir dapat mengutarakan pendapatnya masing-masing tentang hal tersebut. Terlepas dari mana tafsir itu berasal, Islam sangat menjunjung tinggi intelektualitas. Allah kemudian menyuruh para malaikat untuk sujud kepada manusia. Bentuk humanisme yang sangat mendalam, di mana Islam tidak membeda-bedakan makhluk Tuhan berdasarkan dari rasnya melainkan dari tingkat intelektual, kemampuan berfikir (iradah) yang telah dikaruniakan. ${ }^{26}$

Allah menyatakan bahwa manusia dapat menjadi makhluk termulia di antara makhlukmakhluk lain. Suatu hal menarik bahwa hanya manusia yang mau menerima untuk menjadi pemegang dan pengemban amanah Tuhan. Maka jelaslah bahwa manusia memiliki keistimewaan dan keunggulan lain yang menjadikannya makhluk superior. ${ }^{27}$ Demikianlah manusia bukan hanya sekedar khalifah Tuhan di bumi, melainkan juga amanat-Nya. Menurut Maulana Jalal al-Din Rumi, amanat ini memiliki kehendak bebas (free will) manusia. ${ }^{28}$

Sebagai makhluk dua-dimensional, yang dikaruniai misi suci yang agung agar dilaksanakannya di bumi, manusia membutuhkan agama yang dapat memelihara antara kutub keakhiratan dan kutub keduniaan. Disinilah keunggulan Islam, manusia dalam Islam tidak

24 Ali Syari'ati, Tugas Cendekiawan Muslim, 6-7.

25 Ali Syari'ati, Tugas Cendekiawan Muslim, 8.

26 Ali Syari'ati, Manusia dan Islam Sebuab Kajian Sosiologi, 95.

27 Ali Syari'ati, Ummah dan Imamah, Terj Afif Muhhamad, (Bandung: Pustaka Hidayah, 1995), 120-121.

28 Ali Syari'ati, Tugas Cendekiawan Muslim, 11. 
dipandang tanpa daya dihadapan Tuhan dan manusia membutuhkan agama untuk menjaga keseimbangan dua-dimensinya.

\section{Dua Arus Kecenderungan Manusia}

Ali Syari'ati memiliki konsep tentang penciptaan manusia yang terdiri dari dua unsur yang kontradiktif, yaitu lempung yang melambangkan stagnasi atau kerendahan dan ruh Tuhan yang menyimbolkan bagian paling suci dari Tuhan yang terdapat pada setiap manusia. Terjadi peperangan dalam diri manusia antara kerendahan dan kesucian, yang menentukan ke arus mana manusia mengalir. Dua arus kecenderungan manusia yaitu, basyar dan insan. ${ }^{29}$

1. Basyar

Menurut penjelasan Ali Syari’ati Basyar adalah makhluk yang sekedar berada (being). Manusia dalam arusnya sebagai basyar tidak akan mengalami perubahan, ia akan tetap menjadi makhluk berkaki dua berjalan tegak di muka bumi. Secara demikian manusia memiliki definisi yang sama sepanjang zaman terdiri dari karakteristik, biologi, fisologi dan psikologi. Dilihat dari proses penciptaan manusia yang salah satunya adalah lempung, maka unsur lempung ini lebih cenderung ke arus basyar. Tingkat basyar dalam kemanusiaan oleh karena itu dianggap sebagai sesuatu yang rendah.

"Belajar dari perbuatan-perbuatan nista, maka akan ternyata bahwa ia bahkan merupakan makhluk yang lebih inferior, tidak jauh berbeda dari kera,nenek moyangnya yang utama muncur dipermukaan bumi sekitar lima puluh ribu tahun silam. Hanya pakaian, makanan dan tempat tinggal serta senjatanya saja yang sudah berubah, bukan jenis-jeinis maupun kondisinya serta hakikatnya yang rendah. Gengis Khan yang memerintah suatu suku yang buas, atau para kaisar masa lalu, yang menguasai imperium dan peradaban besar, sesungguhnya tidak jauh berbeda dengan para penguasa modern di dunia dewasa ini. Perbedaan sau-satunya adalah bahwa penguasa-penguasa masa lalu tidak memiliki persenjataan modern yang ampuh, yaitu alat-alat dan metode pembunuhan massal dan pemusnahan cepat, karena mereka memang hidup pada dunia yang belum maju. Penguasa masa lalu tidak ragu-ragu mengatakan bahwa mereka sengaja ingin membunuh. Penguasa-penguasa modern yang berperadaban juga telah melakukan pembunuhan, akan tetapi mereka melakukanya demi perdamaian. Hanya retorika pidato, penipuan, pengelabuhan dan raionalisasi sajalah yang telah berubah begitu halus, tetapi esensi kemanusiaan ternyata sama saja." 30

Beberapa bentuk pengejawantahan basyar pada bentuknya yang sudah pasti, manusia yang dalam dimensi fisisnya tidak berubah-ubah. Manusia yang selalu dalam kerendahan dan stagnasi. 


\section{Insan}

Manusia dalam esensinya, sebagai suatu kebenaran yang tinggi, terdiri dari kualitaskualitas ideal yang setiap manusia harus memiliki semangat untuk berusaha mencapainya. Kualitas ini sayang tidak terdapat dalam taraf basyar, namun setiap manusia bisa untuk menciptakanya dalam diri kita bersamaan dengan kemauan untuk bergerak ke taraf men-jadi atau menyempurnakan. Menjadi (becoming) adalah bergerak, maju, mencari kesempurnaan, merindukan keabadian, tidak pernah menghambat dan menghentikan proses terus menerus ke arah kesempurnaan, inilah yang dinamakan taraf insan. ${ }^{31}$ Manusia mampu mencapai taraf ini karena di dalam unsur kerendahan terdapat unsur kesucian atau kemuliaan yaitu ruh Tuhan.

Unsur roh Tuhan yakni sebagai sebutan untuk bagian terhormat yang terdapat dalam perbendaharaan bahasa manusia, suatu konsep terluhur sepanjang akal fikiran manusia harus menjadi azas melajunya kemanusiaan, senantiasa dalam proses mengalir dalam arus kebebasan. ${ }^{32}$ Azas menjadi menunjukan gerak evolusi tanpa henti dari manusia ke arah Yang Tanpa Batas. Kata “ilaibi” pada asalnya berarti kepadaNya, dan ini adalah gagasan pokok Ali Syari'ati tentang menjadi; yakni bergeraknya manusia secara permanen ke arah Tuhan, ke arah kesempurnaan ideal. ${ }^{33}$ Inilah definisi manusia dalam keadaanya menjadi (insan).

\section{Manusia dalam Tahap Proses Menjadi}

Manusia dalam keadaannya menjadi atau proses manusia berusaha menjadi memiliki tiga sifat yang saling berkaitan: kesadaran diri, kemauan bebas dan kreativitas. Bila manusia mempunyai sifat-sifat yang lain, maka itu hanya derivasi atau sifat turunan dari tiga kualitas pokok di atas. ${ }^{34}$ Ketiga prinsip haruslah saling melengkapi dalam suatu cara yang terpadu.

1. Kesadaran Diri

Descartes dalam suatu formula aku berfikir maka aku ada (cogito ergo sum) mendasarkan prinsip kesadaran yang pasti pada diri manusia yang berfikir. ${ }^{35}$ Pada suatu fakta bahwasanya manusia meragukan segalanya dan kemudian membuktikan eksistensi dirinya dengan mengatakan bahwa ia tidak dapat meragukan fakta yang sedang dia sangsikan. Inilah hal yang tidak dapat dipisahkan dariku, aku ada, ini sudah barang tentu selama aku berfikir. ${ }^{36}$ Andre Gide mengungkapkan eksistensinya pada perasaan "aku merasa, maka aku ada”. Sementara

\footnotetext{
31 Ali Syari'ati, Tugas Cendekiawan Muslim.

32 Ali Syari'ati, Manusia dan Islam Sebuah Kajian Sosiologi, 94.

33 Ali Syari'ati, Tugas Cendekiawan Muslim, 69.

34 Ali Syari'ati, Tugas Cendekiawan Muslim, 69.

35 Bertrand Russel, History of Western Philosophy and its Connection with Political and Social Circumstances from the Earliest Time to The Present Day, 740.

${ }^{36}$ Harold H. Titus, Marilyn S. Smith dkk, Persoalan-Persoalan Filsafat, (Jakarta: PT Bulan Bintang, 1984), 79.
} 
Albert Camus mendasarkanya kesadaran itu pada suatu bentuk yang lebih disengaja dan sadar "saya memberontak maka saya ada". Inilah formula-formula dalam proses menjadi, akan tetapi formula terakhir yang memperlihatkan proses menjadi yang sangat dramatis. ${ }^{37}$

Selama manusia hidup tanpa salah, ia justru tidak manusiawi. Hanya dengan memberontak kita menjadi manusia. Ketika ia mengetahui bahwa ditakdirkan tanpa salah dan tidak produktif di surga, maka ia memberontak dengan memakan buah yang dilarang. Buah ini bisa disebut sebagai buahnya pengetahuan, buahnya pemberontakan dan buahnya kesadaran. Demikianlah ia diusir dari surga dan diturunkan di muka bumi ini. ${ }^{38}$

Manusia bukanlah makhluk yang terasing di dunianya, ia ada bersama dengan makhlukmakhluk yang lain dan tidak tertutup pada lingkunganya, akan tetapi hanya manusia yang mampu memiliki eksistensi dibandingkan dengan makhluk bernyawa lainya. ${ }^{39}$ Keberadaan manusia di muka bumi menuntut manusia untuk menyendiri, mengasingkan diri sebagai mana konsep Sartre "delaissement". Manusia akan menjadi sadar bahwa ia berbeda dengan makhluk lain karena dikaruniai kebebasan untuk memilih.

2. Kemauan Bebas

Manusia adalah satu-satunya makhluk yang memiliki kebebsan untuk memilih, bahkan manusia mampu untuk melawan instinknya sendiri, dengan alam, dengan masyarakat atau juga bertentangan dengan dorongan fisik dan psikologisnya. Kemampuan iradahnya atau kebebasannya dalam memilih itulah yang membantu manusia untuk mencapai taraf tertinggi dari proses menjadi manusia. Kemampuan iradahnya mampu untuk menakhlukan gerak keinginan biologisnya yang bersifat defensif. Kebebasan untuk tidak memilih kehidupan yang tenang, kesenangan, kemakmuran dan kemudahan justru sebaliknya mampu untuk memilih kehidupan membangkang dan memberontak, kehidupan disiplin baja yang melawan keinginankeinginan tubuhnya. ${ }^{40}$

3. Kreativitas

Kreativitas manusia atau daya ciptanya yang mampu menciptkan apa saja dalam berbagai bentuk dan berbeda ukuran. Kreativitasnya yang terwujud dalam eksistensi kreatifnya di dalam alam, sebagai suatu makhluk yang khas di muka bumi. Manusia lebih dari sekedar makhluk pembuat, ia juga sebagai makhluk pencipta karena manusia sadar bahwa tidak semua keingininanya disediakan oleh alam. Sepanjang manusia tetap tinggal pada eksistensinya dan bergerak maju, maka alam mampu memenuhi kebutuhan-kebutuhanya.

${ }^{37}$ M Deden Ridwan (ed), Melawan Hegemoni Barat Ali Syariati dalam Sorotan Cendekiawan Indonesia, 88.

38 Ali Syari'ati, Tugas Cendekiawan Muslim, 70.

${ }^{39}$ Sihol Farida Tambunan, "Kebebasan Individu Manusia Abad Dua Puluh: Filsafat Eksistensialisme Sartre", dalam Journal Masyarakat \& Budaya, Vol. 18, No. 2, (2016), 220-221.

40 Ali Syari'ati, Tugas Cendekiawan Muslim, 72-73. 
Manusia dikatakan bereksistensi atau berada di dunia ketika ia mampu keluar dalam dirinya sendiri dan berdiri untuk mengambil bagian dalam dunia. Dunia yang ada pada dirinya sendiri tidak dapat mewujudkan satu dunia, manusia pun kadang-kadang tidak dapat menyatu dengan dunia. Hal ini terjadi bila manusia dan dunia terseret keluar dalam dirinya, tenggelam dan didominasi oleh dunia. Manusia terseret dan tidak bereksistensi secara sungguh-sungguh, ia tidak keluar dalam dirinya sendiri dan menempatkan diri berhadapan dengan yang lain dalam dunia. ${ }^{41}$ Kecerdasan kreativitas manusia ditambah kemampuan iradahnya menuntun manusia untuk menakhlukan alam selangkah demi selangkah, ia membangun suatu sistem industrial yang praktis. $^{42}$

Manusia dengan tiga sifat; kesadaran, kemauan bebas, kreativitas merupakan sifat-sifat dari Tuhan. Akan tetapi hanya manusia taraf insan sajalah yang hanya dapat menyesuaikan dengan sifatsifat Tuhan serta menjadi wakilnya di bumi.

\section{Penjara Manusia}

Ali Syari'ati mengungkapkan terdapat empat penjara determinisme yang menjadi penghambat manusia untuk menuju ketingkat yang lebih sempurna yaitu, sifat dasar atau belenggu alam, sejarah, masyarakat dan ego. Namun dengan usaha yang tinggi manusia dapat membebaskan diri dari empat penjara dan mengubah dirinya dari tingkat makhluk biasa (being) ke manusia tingkat menjadi (becoming). ${ }^{43}$ Semakin baik manusia bergerak ke arah menjadinya, makin baik pula manusia mengungguli kekuatan-kekuatan determinisme. Selama manusia hanya mengurusi eksistensinya saja, ia akan terkurung dalam penjara.

1. Belenggu Alam

Materialisme berpendapat bahwa kecerdasan dan substansi dari manusia berasal dari materi. Demikian halnya menandakan evolusi manusia tidak mampu menembus batas-batas materi. Pandangan ini tidak melihat sedikitpun akan evolusi metafisis di luar zat materialnya, memandang manusia dari ukuran material dan melihat manusia sebagai binatang yang terbatas. Materialisme telah menjadi penghambat bagi manusia untuk melakukan peningkatan dari makhluk yang rendah. ${ }^{44}$

Paham yang menjadikan manusia sebagai korban mulai muncul pada abad ke 18 hingga permulaan abad ke 19. Naturalisme berkeyakinan bahwa segala kehidupan berawal pada makhluk yang tidak memiliki kesadaran, yaitu alam dan manusia merupakan salah satu dari

${ }^{41}$ Sindung Tjahyadi, "Manusia dan Historisnya Menurut Martin Heidegger", dalam Journal Filsafat, Vol. 18, No. 1, (April 2008), 51.

42 Ali Syari'ati, Tugas Cendekiawan Muslim, 74.

${ }^{43}$ M Deden Ridwan (ed), Melawan Hegemoni Barat Ali Syariati dalam Sorotan Cendekiawan Indonesia, 90.

44 Ali Syari'ati, Tugas Cendekiawan Muslim, 76. 
produk alam. ${ }^{45}$ Naturalisme menempatkan manusia sebagai makhluk yang paling maju di alam, akan tetapi naturaslisme mensubordinasikan manusia di bawah alam.

Ibn Khaldun mengatakan bahwa setiap kehidupan masyarakat didasarkan pada kondisi geografisnya. Menjadi seorang pemburu atau petani ditentukan oleh keadaan alam, tidak ada yang mampu mengingkari peranan alam dalam membentuk seorang manusia. demi menyambung hidupnya, manusia menunggu alam agar menurunkan hujan supaya bisa bercocok tanam. Pendapat ini mungkin benar jika ditempatkan pada sejarahnya masa lalu, akan tetapi tidak pada masa sekarang. Semakin maju manusia bergerak ke arah menjadinya, semakin baik ia mengungguli kekuatan-kekuatan dari belenggu alam. ${ }^{46}$

2. Sejarah

Aliran historisisme mempunyai sebuah anggapan bahwa manusia merupakan sebuah hasil dari sejarah. Historisisme beranggapan bahwa dialah yang menentukan manusia, apa yang harus di tempuh dan bagaimana manusia harus mengarah. Sejarah Iran, Islam dan Syi'ah telah membentuk kepribadian Ali Syari'ati. Semisal hidup pada revolusi Perancis, tentu akan memiliki bahasa, sentimen dan karakter yang berbeda, oleh karena itu karakter manusia jatuh pada kehendak historisisme. ${ }^{47}$ Begitu pula alam membentuk warna kulit, sedangkan sejarah memilih membentuk warna jiwa. Pada kenyataanya, semua manusa dilahirkan dan dibesarkan di dalam masyarakat yang telah ditentukan dan dipola oleh sejarah. ${ }^{48}$

3. Masyarakat

Aliran sosiologi memiliki keyakinan bahwa lingkungan masyarakat dan tatanan sosial yang membentuk manusia. Apabila seseorang menjadi manusia yang murah hati, hal ini disebabkan oleh tatanan masyarakat yang feodalistik. Tetapi jika manusia itu haus uang dan sadar dagang, berarti ia dibesarkan dalam masyarakat borjuis. Apabila ia seorang penunggang kuda, kasar dan resah, itu menandakan bahwa ia hidup di lingkungan tribalistik. Adapun nanti timbul manusia dengan sifat yang lain, maka itu disebabkan karena ia telah dibesarkan dalam masyarakat yang lain. Lebih jauh lagi bahwa tatanan sosial dan hubungan-hubungan sosial dibentuk oleh hubungan-hubungan ekonomi, alat-alat produksi, barang-barang pabrik, hubungan antar kelas, tradisi; keyakinan dan praktek moral serta religi, upacara-upcara ibadah dan lain-lain. ${ }^{49}$

${ }^{45}$ Charles Kurzman (ed), Wacana Islam Liberal Pemikiran Islam Kontemporer Tentang Isu Isu Global, (Jakarta: Paramadina, 2001), 306.

46 Ali Syari'ati, Tugas Cendekiawan Muslim, 88.

${ }^{47}$ Charles Kurzman (ed), Wacana Islam Liberal Pemikiran Islam Kontemporer Tentang Isu Isu Global, 308.

48 Ali Syari'ati, Tugas Cendekiawan Muslim, 82.

49 Ali Syari'ati, Tugas Cendekiawan Muslim, 82. 
Lingkungan sosial yang membentuk tindakan dan watak manusia sekarang atau masa depan, yang berarti bahwa seorang individu tidak dapat dimintai tanggung jawab atas tindakannya, yang baik maupun buruk. Aliran sosiologis menolak adanya peranan individu dalam membentuk nasibnya. ${ }^{50}$ Sosiologisme memiliki prinsip yang kuat bahwasanya seorang individu dibentuk oleh sekelompok masyarakat, bukan oleh dirinya sendiri sebagai individu. Menjadi manusia berarti melakukan pilihan, maka sosiologisme tidak mau menerima sebagai makhluk yang dapat bereksistensi menyatakan "keakuanya" dan individualitasnya.

Manusia seringkali terombang-ambing dalam melakukan pilihan, bahkan tidak dapat memilih untuk dirinya sendiri. Sosiologisme berpendirian bahwa dilema seperti ini yang dialami oleh manusia merupakan ciptaan masyarakat. Ketika manusia dihadapkan dengan dua isu sosial yang berbeda, ia mulai ragu-ragu dan terombang ambing dalam kedua faktor tersebut. Sosiologisme menyatakan bahwa seorang yang ragu-ragu, apakah ia harus beragama atau tidak, apakah ia harus teis atau ateis, bukan karena ia dapat memilih salah satu, tetapi karena kedua faktor berlainan itu terdapat di dalam masyarakatnya. Polaritas masyarakat mampu untuk mempengaruhi alam berfikir manusia. ${ }^{51}$

4. Ego

Ego merupakan penjara terburuk, karena terdapat di dalam manusia itu sendiri. Ego inilah yang menjadikan penjara lainnya sia-sia, meski manusia sekarang memiliki pengetahuan dan kemampuan lebih dibandingkan dengan masa manapun sepanjang sejarah, namun sedikit manusia yang mengetahui tentang apa yang harus diperbuat. Manusia modern telah menemukan berbagai macam apa yang harus ia lakukan untuk menghadapi berbagai persoalan kehidupanya, namun ia belum mengetahui bagaimana caranya keluar dari penjara gelap dalam dirinya yang rendah. ${ }^{5}$

Penjara ego memanglah jauh berbeda dari penjara yang lain, ego memenjara di dalam dirinya dan sulit untuk dicapai, karena tidak konkrit, tidak eksternal, tidak dapat diraba dan tidak tentu. Penjara yang lainnya dapat diketahui secara sadar karena berada di luar dirinya, seperti halnya manusia primitive yang harus bergantung pada perburuan karena dia menyadari bahwa hidupnya di sekitar hutan dan sungai. Menyadari bahwa manusia tidak dapat melawan daya tarik bumi karena tidak bisa terbang. ${ }^{53}$ Penjara yang lain memiliki batas-batas yang jelas berbeda dengan penjara ego yang batas-batas atau lokasinya tidak dapat dibuat petanya atau diukur.

\footnotetext{
${ }^{50}$ Charles Kurzman (ed), Wacana Islam Liberal Pemikiran Islam Kontemporer Tentang Isu Isu Global, 309.

51 Ali Syari'ati, Tugas Cendekiawan Muslim, 84.

52 Ali Syari'ati, Tugas Cendekiawan Muslim, 92-93.

53 Ali Syari'ati, Tugas Cendekiawan Muslim.
} 
Terdapat beberapa prinsip umum yang mampu menggambarkan penjara ego: ${ }^{54}$ Manusia memiliki kebutuhan; Manusia akan berusaha untuk memenuhi kebutuhanya agar memperoleh kenyamanan dalam hidup; Kenyamanan akhirnya berujung pada kesia-siaan; Perasaan sia-sia kemudian melahirkan pemberontakan; Pemberontakan akan berakhir pada asketisme dan subyektifitas.

Maka dari itu jelaslah mereka terkungkung dalam determinisme mereka sendiri. Masyarakat borjuis sekarang ini telah mencapai jalan buntu, karena lebih menekankan hidupnya pada konsumsi dan materialisme. Penyebab manusia mencapai suatu absurditas yakni karena menekankan secara berlebihan pada cita-cita yang materialistik. Cita-cita yang telah menghasilkan lebih banyak frustasi dan kesia-kesiaan daripada kepuasan yang sebenarnya. ${ }^{55}$ Selama manusia terpenjara oleh egonya, ia akan menjadi seorang pelomba yang pasti akan bangkrut.

"Ia tak ubahnya seperti seorang pangeran, seperti yang dilukiskan oleh Jaun Izula, yang berkilauan dengan emas, permata dan kendaraan bersenjata, akan tetapi di bawah gemerlapnya barang-barang tersebut sang pangeran menderita penyakit berat yang ia belum menemukan obatnya." 56

Analogi sang pangeran dengan emas, permata dan dijaga oleh kendaraan bersenjatanya mengibaratkan manusia pada zaman modern, akan tetapi pada hakikatnya ia lebih lemah dan ringkih dari zaman-zaman sebelumnya. Pusat intelektual Eropa, di Cambridge dan Sorbonne melakukan perdagangan para kaum intelektual yang sangat pintar dalam suatu pelelangan untuk harga yang menjulang tinggi. Sesungguhnya mereka sendirilah yang menawarkan dirinya dihadapan kapitalis, agen-agen korporasi dan perusahaan-perusahaan demi untuk mendapatkan uang. Sayang sekali manusia yang sangat cerdas ini secara moral sangat lemah, terikat oleh upah dan benda-benda materialistik lainya. ${ }^{57}$ Secara professional, sesungguhnya kaum intelektual ini mampu membantu masyarakat dalam memecahkan masalah dan berbagai rintangan kehidupan, akan tetapi manusia terlalu lemah untuk membebaskan diri dari penjara yang ada di dalam dirinya. Perlawanan untuk membebaskan dari penjara ini harulah dimulai dengan pemberontakan dari dimensi-dimensi di dalam diri manusia.

\section{Humanisme dalam Derasnya Kemajuan Teknologi}

Manusia adalah hal terpenting dari semua masalah yang pernah ada dalam peradaban. Pergantian peradaban disertai dengan perjuangan manusia untuk dapat bertahan hidup.

\footnotetext{
${ }^{54}$ Charles Kurzman (ed), Wacana Islam Liberal Pemikiran Islam Kontemporer Tentang Isu Isu Global, 313.

55 Charles Kurzman (ed), Wacana Islam Liberal Pemikiran Islam Kontemporer Tentang Isu Isu Global.

56 Ali Syari'ati, Tugas Cendekiawan Muslim, 95.

57 Ali Syari'ati, Tugas Cendekiawan Muslim, 96-97.
} 
Humanisme kini menjadikan manusia sebagai pusatnya di atas dunia, karena sebelumnya keyaninan masa lalu merendahkan manusia. pendegradasian manusia dengan esensinya dan atas statusnya di dunia, diakibatkan oleh keyakinan-keyakinan masa lalu, yang mau tidak mau membangkitkan spirit humanisme di zaman renaissance. Sejak saat itu, hingga kini humanisme dianggap sebagai paham modern yang mengagungkan manusia. ${ }^{58}$

Sartre mengatakan, manusia adalah apa yang ia cita-citakan, manusia ada sejauh dia merealisasikan dirinya sendiri, dan oleh karena itu dia adalah representasi keseluruhan dari tindakan-tindakannya. Manusia tidak akan menjadi apa-apa kecuali apa yang telah dinyatakan dalam tindakan oleh hidupnya. Jantung humanisme Sartre teletak pada sifat absolut pilihan bebas, dengan pilihan bebas ini manusia mewujudkan dirinya dalam merealisasikan suatu kemanusiaan. ${ }^{59}$

Menurut Ali Syari'ati yang berangkat dari dogma agama Islam mengutarakan bahwasanya, humanisme dalam Islam telah tergambarkan dalam proses penciptaan Adam. Menjadikannya manusia sebagai subjek di atas bumi. Mengagungkan manusia bukan dari ras atau asal mereka diciptakan, akan tetapi dari kemampuan mereka dalam berfikir. ${ }^{60}$ Pada taraf menjadi (insan) manusia, mempunyai kemampuan berfikir yang diturunkan menjadi tiga atribut atau watak yakni, kesadaran diri, kemauan bebas dan kreativitas. Ketiga watak ini akan senantiasa membawa manusia dalam proses menjadi (insan) yang tanpa batas.

Penemuan-penemuan yang terjadi dalam peradaban merupakan hasil dari kemauan bebas dan daya kreativitas manusia. Teknologi dikembangkan oleh manusia sebagai perpanjangan tangan untuk mempermudah kehidupanya. Pada mulanya gaya gravitasi yang dicetuskan oleh Newton, kini mampu ditundukan oleh Wright bersaudara dengan keberhasilan dalam menerbangkan Wright Flyer di Kitty Hawk, North Carolina pada tahun 1903. ${ }^{61}$ Pertanian tidak perlu lagi bergantung pada curah hujan dengan ditemukanya hujan buatan melalui penyemaian awan oleh peneliti asal Amerika yang bernama Vincent Joseph Schaefer pada tahun $1946 .{ }^{62}$ Gangguan-gangguan yang disebabkan oleh musim kemarau, hama, dan bencana alam kini mampu ditangani oleh teknologi. Penemuanpenemuan ini dalam rangka memudahkan manusia dalam beraktifias dan bertahan hidup sehingga teknologi dapat dipandang sebagai objek penyelamat manusia dari belenggu alam. ${ }^{63}$

58 Ali Syari'ati, Tugas Cendekiawan Muslim, 1.

59 Jean Paul Sartre, Existensialism and Humanism, Terj Yudhi Murtanto, (Yogyakarta: Pustaka Pelajar, 2002), 73-86.

${ }^{60}$ Ali Syari’ati, Manusia dan Islam Sebuah Kajian Sosiologi, 89.

61 Aswab Nanda Pratama, "7 Fakta Menarik Wright Bersaudara, Penemu Pesawat Terbang”, (Kompas.com, 17 Desember 2018, 14.30 WIB) diakses pada 21 April 2019, 03.15 WIB.

62 Aswab Nanda Pratama, "Kisah Vincent J Schaefer, Orang Pertama yang Turunkan Hujan Buatan", (Kompas.com, 16 November 2018, 15.30 WIB), diakses pada 21 April 2019, 03.25 WIB.

63 Ali Syari'ati, Tugas Cendekiawan Muslim, 89. 
Meskipun teknologi dikecam karena telah melakukan dehumanisasi dan mengorbankan sebagian manusia, setidaknya dia dapat digunakan untuk mempermudah dan meringankan beban kerja manusia. Pada abad 18 ditemukanya mesin uap sebagai tanda awal revolusi industri yang membantu manusia dalam ranah fisik. Produksi kain dengan menggunakan mesin uap mampu menghasilkan kain yang bagus secara kualitas dan kuantitas. Mesin uap memungkinkan produksi dalam ruang dan ritme yang senantiasa terkendali dan tidak lagi bergantung pada musim, cuaca dan faktor-faktor alam lainya. ${ }^{64}$ Mesin uap ini secara tidak langsung menimbulkan hilangnya sebagian pekerjaan para penenun kain, yang sebelumnya kain itu ditenun dari kapas oleh manusia secara manual kini digantikan oleh mesin. Pergulatan mesin uap dan manusia ini dimenangkan oleh manusia, karena mesin hanya mengambil bagian manusia dalam ranah fisik dan manusia memiliki dua ranah yakni fisik dan kognitif. Manusia kemudian beralih menjadi operator-operator mesin yang membutuhkan kemampuan dalam berfikir.

Pada abad 20 akhir ditemukan komputer, sebuah mesin dengan tenaga listrik yang dilengkapi tombol-tombol sederhana. Komputer juga digunakan dalam produksi massal, sama seperti mesin uap, hanya saja komputer lebih canggih dengan kemampuanya dalam menghitung dan tombol-tombol perintah yang mempermudah manusia. Sistem yang hampir serupa dengan mesin uap, menjadikan manusia sebagai operator dan tetap unggul dalam ranah kognitif. Sampai saat itu teknologi masih menjadi alat perpanjangan manusia dalam rangka mempermudah dan meringankan tugas manusia.

Manusia harus senantiasa mengarahkan diri kepada kesempurnaan. Bagi Nietzsche, sasaran yang dituju ialah manusia agung. Seperti halnya manusia taraf menjadi (insan). Masa depan manusia merupakan suatu proses menjadi lebih baik, pemusatan yang lebih tinggi. Manusia bukan sesuatu yang ketika usai diciptakan maka sudah selesai. Ia harus berikhtiar dan merealisasikan diri secara terus menerus untuk melampaui dirinya untuk mencapai derajat manusia yang agung. ${ }^{65}$ Manusia diturunkan di dunia menjadi wakil Tuhan (penguasa alam semesta), oleh karena itu manusia harus tetap menjadi subjek, menjadi pusat dalam tatanan alam semesta, menjadi makhluk yang bebas dan bermartabat.

Menurut Abraham Maslow tingkah laku manusia lebih ditentukan pada kecenderungan individu untuk mencapai tujuan hidup yang berbahagia dan sekaligus kepuasan dalam kesadaran. Humanisme Maslow menyandarkan pada kepribadian secara keseluruhan yang integral, khas, sistematis yang mampu menunjukan eksistensi manusia memiliki kebebasan untuk memilih. ${ }^{66}$ 2003), 100.

${ }^{64}$ Hans Fink, Filsafat Sosial Dari Feodalisme Hingga Pasar Bebas, Terj Sigit Jatmiko, (Yogyakarta: Pustaka Pelajar,

${ }^{65}$ Friedrich Nietzsche, Kehendak. Untuk Berkuasa, Terj Chairul Arifin, (Jakarta: Erlangga, 1987), 57.

${ }^{66}$ Nur Hikma, "Aspek Psikologi Tokoh Utama Dalam Novel Sepatu Dahlan Karya Krhisna Pabichara (Kajian Psikologi Humanistik Abraham Maslow)”, dalam Journal Humanika No. 15, Vol. 3, (Desember 2015$), 4$. 
Kebebasan dalam manusia menurut Ali Syari'ati adalah karunia dari Tuhan. Berkat ditiupkanya ruh Tuhan, manusia mampu melakukan apa saja bahkan menolak kebutuhan fisiknya. Tuhan, satusatunya Dzat dengan kemauan mutlak yang memiliki kekuasaan untuk melakukan apa saja yang Ia kehendaki. Sifat-sifat-Nya secara langsung turun kepada manusia sehingga mampu berbuat menyerupai Tuhan, namun tidak mampu untuk menyamai Tuhan. ${ }^{67}$

Pada abad 21 terjadi kemajuan yang pesat, manusia tidak lagi menyandarkan keyakinan kepada Tuhan, mereka lebih mempercayai hasil temuan-temuan dari para ilmuan. Kematian tidak lagi dipandang sebagai sesuatu yang sakral, sekarang ini kematian dianggap sebagai kesalahan teknis dalam organ tubuh manusia. Jantung berhenti memompa, arteri utama tersumbat lemak, sel-sel kanker menyebar di hati, kuman berbiak di paru-paru dan lain sebagainya. Semua ini dianggap sebagai bagian dari kesalahan teknis dan pasti memiliki solusi teknis. Membunuh sel kanker dengan komoterapi, menghidupkan jantung yang berhenti memompa dengan listrik kejut, jika tidak berhasil bisa dengan mencangkokkan jantung yang baru. ${ }^{68}$ Kemajuan-kemajuan ini berkat kepercayaan manusia atas dirinya sendiri yang mulai menaruh harapan dan memberikan saham untuk riset-riset terbaru kepada para ilmuan.

Perkembangan pesat dalam sains seperti algoritma biokimia, hukum matematika dan elektronik yang bergabung kemudian menjadikan temuan terbaru yakni AI (Artificial Intelegent). AI memiliki kemampuan luar biasa bahkan mampu mengungguli manusia. Watson IBM dengan sistem AI memenangkan dalam acara permainan TV Jeopardy pada 2011, mengalahkan manusia yang sebelumnya menjadi juara. ${ }^{69}$ Pada 10 Februari 1996, Deep Blue yang dirancang oleh IBM mengalahkan Garry Kasparov juara catur dunia. Beberapa tahun kemudian, AI mencapai sukses yang lebih sensasional, ketika perangkat lunak AlphaGo milik Google mengajari dirinya bagaimana memainkan Go (sebuah permainan papan strategi kuno China). Kerumitan Go sudah lama dianggap jauh dari jangkauan program AI. Suatu pertandingan diadakan di Seoul pada Maret 2016 antara AlphaGo dan juara Go Korea Selatan yaitu Lee Sedol. AlphaGo menggulung Lee 4-1 dengan langkah-langah yang tidak lazim. ${ }^{70} \mathrm{AI}$ mampu membaca dengan baik langkah-langkah yang akan dilakukan oleh manusia, kemudian memberikan perlawan dengan strategi orisinal yang mencengangkan. Tonggak terpenting tercapai bukan ketika komputer mampu mengalahkan manusia dalam permainan catur, tetapi ketika program Google AlphaZero mengalahkan program Stocfish 8 pada 7 Desember 2017. Stocfish adalah juara catur komputer dunia tahun 2016. Stocfish memiliki akses ke akumulasi pengalaman manusia selama berabad-abad, ditambah dengan puluhan

\footnotetext{
${ }^{67}$ Ali Syari'ati, Tugas Cendekiawan Muslim, 12.

68 Yuval Noah Harari, Homo Deus a Brief History of Tomorrow, 25-26.

${ }^{69}$ Yuval Noah Harari, Homo Deus a Brief History of Tomorrow, 362.

${ }^{70}$ Yuval Noah Harari, Homo Deus a Brief History of Tomorrow, 368-369.
} 
tahun pengalaman komputer. Stocfish mampu menghitung 70 juta posisi catur dalam hitungan detik. Sementara AlphaZero hanya melakukan 80.000 perhitungan perdetik dan tidak dibekali pengajaran tentang strategi catur, bahkan bukaan standar sekalipun. AlphaZero menggunakan prinsip pembelajaran mesin terbaru, sehingga kemampuanya selalu berkembang ketika semakin banyak bermain. Semula AlphaZero sepenuhnya tidak tahu, hanya dengan 4 jam untuk mengembangkan naluri, ia mampu menjadi master catur tanpa bantuan manusia. ${ }^{71}$ Teknologi sekarang ini mampu memperbarui dirinya sendiri hanya dengan beberapa jam. Catur menjadi salah satu permainan yang menunjukan puncak kecerdasan manusia selama berabad-abad dan kini secara pemikiran dalam permainan catur teknologi mampu lebih baik daripada manusia. Tidak hanya dalam permainan, teknologi kini mampu menjawab masalah dalam kehidupan nyata global dalam segala bidang kehidupan manusia.

Spirit humanisme Ali Syari’ati berkeyakinan kepada individu manusia yang memiliki esensi tunggal mampu berfikir dalam kesadaran diri, kemauan bebas dan kreativitas. Memiliki kebebasan kehendak yang hanya ada dalam diri individu, memiliki hak otoritas penuh atas tubuhnya. ${ }^{72}$ Teknologi Abad-21 memungkinkan untuk meretas kemanusiaan dan mengenal individu jauh lebih baik daripada diri sendiri. Keyakinan atas kemampuan individu runtuh dan otoritas beralih dari manusia ke jaringan data algoritma. Instagram yang mampu mendefinikan manusia lebih baik daripada manusia itu sendiri. Netflix yang mampu merekomendasikan film yang terbaik untuk manusia. Google yang mampu memberikan jawaban atas pertanyaan-pertanyaan manusia. WatsonIBM yang sangat memungkinkan mampu melihat kesehatan manusia dengan sensornya dan memeriksa kadar gula dalam tubuh manusia, kemudian memperingatkan manusia ketika mencapai ambang batas. ${ }^{73}$

Semua dalam kehidupan manusia mampu dijelaskan oleh AI dengan sangat baik, bahkan kehidupan manusia sekarang dituntun oleh AI. Sebuah firma modal di Hongkong, pada Mei 2014 Deep Knowledge Ventures yang spesialis obat regeneratif, menunjuk sebuah algoritma yang diberi nama Vital untuk mengisi jabatan komisaris. Seperti dewan komisaris lainya, Vital mempunyai hak untuk menentukan apakah firma perlu melakukan investasi di perusahaan tertentu atau tidak, dengan mendasarkan opininya pada kalkulasi-kalkulasi analisis cermat tumpukan besar data. Kepercayaan manusia untuk kemajuan perusahaan kini diserahkan kepada AI, sehingga AI kini menuntun kearah mana perusahaan akan melakukan investasi yang tepat. Tidak perlu lagi

${ }^{71}$ Yuval Noah Harari, 21 Lessons for the 21 ${ }^{\text {st }}$ Century, 34-35.

${ }^{72}$ Ali Syari'ati, Tugas Cendekiawan Muslim, 69.

${ }^{73}$ Yuval Noah Harari, Homo Deus a Brief History of Tomorrow, 382. 
mengadakan rapat dengan banyak orang, karena AI mampu mengkalkulasikan banyak kemungkinan dengan cepat dan mampu menyimpulkan mana yang menguntungkan. ${ }^{74}$

September 2013 terbitlah buku The Future of Employment yang ditulis oleh dua peneliti Oxford, Carl Benedikt Frey dan Michael A. Osbone, mencerikan kemungkinan beragam profesi yang akan di ambil alih oleh algoritma komputer dalam 20 tahun mendatang. 47\% pekerjaan di Amerika Serikat berada pada resiko tinggi. Misalnya, ada 99\% telemarketer dana agen asuransi manusia akan di ambil alih oleh algoritma pada tahun 2033. Ada kemungkinan $98 \%$ hal yang sama menimpa pada wasit olahraga, 97\% terjadi pada kasir, 96\% menimpa koki. Pelayan restoran 94\%. Pemandu wisata 91\%. Pengemudi Truk $89 \%$, dan pekerjaan-pekerjaan lainya. ${ }^{75}$

Manusia mungkin menjadi tidak berguna dihadapan algoritma. Otoritas secara perlahan mulai bergeser dari manusia ke algoritma. Manusia lebih mempercayai Instagram, Netflix, Google dan bentuk-bentuk AI lainya. Tanpa adanya data-data tersebut manusia akan merasa kehilangan sebagian dari dirinya. Jika kita berfikir, siapa yang menulis Instagram, Facebook, Wikipedia? Kita semua, manusialah yang telah mengisinya. Individu manusia hanya menjadi komponen mungil dalam sebuah sistem yang tak seorang pun benar-benar memahaminya. Setiap hari manusia menyerap, menulis dan membagikan data yang tak terhitung jumlahnya melalui smartphone, komputer dll. Manusia tidak tau di mana kedudukanya dalam skema hal-hal yang lebih besar karena berada dalam tumpukan data yang tercipta dari milliaran manusia dan saling terhubung. Manusia terlalu sibuk melihat jumlah like dan menanggapi komentar dari postingan indahnya senja di sore hari, tanpa menyadari sebenarnya apa yang telah dia lakukan di hari itu. Teknologi kini mendefinisikan manusia adalah data yang telah dia proses. ${ }^{76}$

Humanisme pada abad 21 runtuh dihadapan revolusi teknologi. Jiwa atau nafas humanisme terletak pada individu manusia, kebebasan memilih dan subjektifitas manusia sebagai pusat kehidupan didunia, namun hal itu hilang dihadapan teknologi. Kehendak manusia sekarang disandarkan kepada AI, belok ke kiri atau ke kanan meski hati nurani manusia itu ingin belok ke kiri akan tetapi google mengatakan ke kanan, maka manusia kini lebih mempercayai google dan mengambil keputusan belok ke kanan. Teknologi yang seharusnya menjadi alat perpanjangan dari manusia, menjadi objek penolong bagi manusia, justru mengambil alih tugas manusia sebagai subjek diatas bumi. Manusia hilang dalam arus deras data yang saling bertumpukan. Manusia yang menurut pandangan humanisme Sartre dan dalam Filsafat manusia Ali Syari'ati adalah sebagai pusat dari kehidupan, sebagai wakil Tuhan yang ada di bumi, kini manusia hanya menjadi sebuah komponen mungil dari sistem.

74 Yuval Noah Harari, Homo Deus a Brief History of Tomorrow, 371.
75 Yuval Noah Harari, Homo Deus a Brief History of Tomorrow, 375.
76 Yuval Noah Harari, Homo Deus a Brief History of Tomorrow, 443. 
Sifat dari manusia Insan (dalam tahap proses menjadi) harus senantiasa dimiliki. Sebuah keadaan kehidupan pasti akan selalu bekembang, hal itu disebabkan oleh pengaruh beberapa manusia yang selalu mengembangkan daya kreatifitasnya. Demi mewujudkan suatu kesadaran dan kebebasan manusia secara kolektif maka manusia haruslah memahami bahwa setiap manusia memiliki fitrah sebagai pusat dari kehidupan dan tugas suci yakni menjadi wakil Tuhan. Kesadaran diri, kemauan bebas dan daya kreatifitas yang melekat akan membantu setiap manusia untuk keluar dari penjara-penjara subtantif yang membelenggu. Apapun bentuk transformasi penjara tersebut, selama 3 sifat ini masih dimiliki, niscaya penghalang determinan mampu untuk terlewati. Oleh karena itu, manusia akan selalu berkembang menuju manusia yang unggul, memiliki kesadaran dan kebebasan penuh terhadap otoritas tubuhnya, serta menjadi pusat dari kehidupan.

\section{Kesimpulan}

Kemajuan teknologi memang tidak mampu lagi untuk dipungkiri. Sebuah penemuan menakjubkan dari sejarah umat manusia. Teknologi AI yang dirancang manusia berhasil melakukan pekerjaan manusia bahkan dengan lebih baik. Membantu merekomendasikan hal baik dari setiap kehendak manusia. Teknologi kini yang terlalu memanjakan manusia, membuat manusia kehilangan substansi sebagai manusia. Manusia larut dalam tumpukan data, sehingga membuat hilangnya kesadaran atas eksistensi dirinya. Manusia secara individu mempunyai kebebasan untuk menciptakan kemungkinan-kemungkinan yang ada dengan mendefinisikan diri sendiri, meletakan seluruh tanggung jawab manusia di pundak manusia itu sendiri. Setiap manusia yang berusaha menuju pada manusia unggul atau Insan (dalam proses menjadi) memiliki sifat kesadaran diri, kemauan bebas, dan daya kreatifitas. Sehingga dengan adanya 3 sifat itu manusia berhak menentukan dan menemukan pilihanya sendiri dan mampu bertahan dari segala yang membelenggu kebebasanya serta imajinasi-imajinasi yang menghilangkan kesadarannya.

\section{Referensi}

Daliman. Manusia dan Sejarah. Yogyakarta: Penerbit Ombak. 2012.

Fink, Hans. Filsafat Sosial Dari Feodalisme Hingga Pasar Bebas. Terj Sigit Jatmiko. Yogyakarta: Pustaka Pelajar, 2003.

Foucault, Michel. Power or Knowledge. Terj Yudi Santosa. Yogyakarta: Bentang Budaya. 2002.

Harold H. Titus, Marilyn S. Smith dkk, Persoalan-Persoalan Filsafat. Jakarta: PT Bulan Bintang. 1984. Harrari, Yuval Noah. 21 Lessons for the $21^{\text {st }}$ Century. Terj Haz Algebra. Manado: CV. Global Indo

Kreatif. 2018. 
Harrari, Yuval Noah. Homo Deus a Brief History of Tomorrow. Terj Yanto Mustofa. Tanggerang Selatan: PT Pustaka Alfabet. 2018.

Harrari, Yuval Noah. Sapiens. Terj Damaring Tyas Wulandari Palar. Jakarta: PT Gramedia. 2018.

Heriyanto, Husain. Revolusi Saintifike di Iran. Jakarta: Universitas Indonesia Press. 2013.

Hikma, Nur. "Aspek Psikologi Tokoh Utama Dalam Novel Sepatu Dahlan Karya Krhisna Pabichara (Kajian Psikologi Humanistik Abraham Maslow)”. dalam Joumal Humanika No. 15, Vol. 3. (Desember 2015).

Kurzman, Charles (ed). Wacana Islam Liberal Pemikiran Islam Kontemporer Tentang Isu Isu Global. Jakarta: Paramadina. 2001.

Nietzsche, Friedrich. Kehendak Untuk Berkuasa. Terj Chairul Arifin. Jakarta: Erlangga. 1987.

Pratama, Aswab Nanda. "7 Fakta Menarik Wright Bersaudara, Penemu Pesawat Terbang". (Kompas.com, 17 Desember 2018, 14.30 WIB)

Pratama, Aswab Nanda. "Kisah Vincent J Schaefer, Orang Pertama yang Turunkan Hujan Buatan”. (Kompas.com, 16 November 2018, 15.30 WIB)

Ridwan, M Deden (ed). Melawan Hegemoni Barat Ali Syariati dalam Sorotan Cendekiawan Indonesia. Jakarta: PT Lentera Basritama. 1999.

Russel, Bertrand History of Western Philosophy and its Connection with Political and Social Circumstances from the Earliest Time to The Present Day, Terj Sigit Jatmiko dkk. Yogyakarta: Pustaka Pelajar. 2016.

Sabara. "Pemikiran Teologi Pembebasan Ali Syari'ati". dalam Journal Al-Fikr Vol. 20, No. 2. (September 2016).

Sartre, Jean Paul. Existensialism and Humanism. Terj Yudhi Murtanto. Yogyakarta: Pustaka Pelajar. 2002.

Syari’ati, Ali. Agama Versus “Agama”. Terj Afif Muhammad. Bandung: Pustaka Hidayah. 1994.

Syari'ati, Ali. Manusia dan Islam Sebuah Kajian Sosiologi. Terj Ashar R W. Yogyakarta: Cakrawangsa. 2017.

Syari'ati, Ali. Sosiologi Islam Pandangan Dunia Islam dalam Kajian Sosiologi untuk Gerakan Sosial Baru. Terj Arif Mulyadi. Yogyakarta: Rausyan Fikr Institute. 2011.

Syari’ati, Ali. Tugas Cendekiawan Muslim. Terj M. Amien Rais. Jakarta: Rajawali. 1987.

Syari'ati, Ali. Ummah dan Imamah. Terj Afif Muhhamad. Bandung: Pustaka Hidayah. 1995.

Tambunan, Sihol Farida. "Kebebasan Individu Manusia Abad Dua Puluh: Filsafat Eksistensialisme Sartre". dalam Journal Masyarakat \& Budaya Vol. 18, No. 2. (2016).

Tjahyadi, Sindung. "Manusia dan Historisnya Menurut Martin Heidegger". dalam Journal Filsafat Vol. 18, No. 1. (April 2008). 
